\title{
MENGGAGAS PENDIDIKAN ISLAM RESPONSIF GENDER
}

\author{
Oleh: \\ Dwi Ratnasari \\ UIN Sunan Kalijaga Yogyakarta
}

\begin{abstract}
ABSTRAK
Islam diturunkan ke dunia hanya untuk membebaskan manusia dari semua bentuk ketidakadilan. Dalam hubungan laki-laki dan perempuan, keadilan mensyaratkan tidak ada diskriminasi, tidak ada kecenderungan mengistmewakan jenis kelamin tertentu dan merendahkan jenis kelamin yang lain. Keadilan memberikan bobot yang sama dalam hak dan tanggung jawab baik perempuan maupun laki-laki. Keadilan tidak menempatkan perempuan sebagai subordinasi laki-laki. Ada prinsip-prinsip keadilan dalam hubungan laki-laki dan perempuan yang terkandung di dalam nilai-nilai Islam universal. Pendidikan Islam sebagai proses transformasi nilai-nilai Islam mempunyai peran penting dalam membentuk masyarakat agar memiliki kepekaan sensitive gender. Posisi tidak setara antara peran laki-laki dan perempuan bukanlah bagian dari pendidikan Islam. Oleh karena itu, perlu dikembangkan konsep pendidikan Islam responsif gender yang memberikan kesempatan sama baik bagi laki-laki maupun perempuan untuk mengembangkan potensi dirinya secara optimal.
\end{abstract}

Kata kunci: pendidikan, Islam, responsif gender, keadilan.

\begin{abstract}
Islam was revealed to the world only to free humanity from all forms of injustice. In the relationship of men and women, justice requires no discrimination, there is no tendency to let down certain sexes and demean other sexes. Justice provides equal weight in the rights and responsibilities of both women and men. Justice does not place women as subordinate to men. There are principles of justice in the relations of men and women contained in universal Islamic values. Islamic education as a process of transforming Islamic values has an important role in shaping society to have gender sensitive sensitivity. The unequal position between the roles of men and women is not part of Islamic education. Therefore, the concept of gender responsive Islamic education needs to be developed which provides equal opportunities for both men and women to develop their potential optimally.
\end{abstract}

Keywords: education, Islam, gender responsiveness, justice.

\section{PENDAHULUAN}

Seiring dengan meningkatnya
kesadaran masyarakat tentang
pentingnya kesetaraan gender dalam
relasi laki-laki dan perempuan,
pendidikan Islam responsif gender saat
ini menjadi sebuah kebutuhan, terutama

bagi kalangan orang tua yang meyakini bahwa dengan menanamkan nilai-nilai adil gender dalam pendidikan anak-anak akan menghasilkan generasi yang berperspektif gender dalam memperlakukan anak-anaknya kelak sehingga dapat terwujud masyarakat 
yang berwawasan gender, yang memperlakukan laki-laki dan perempuan secara adil, setara dan harmonis.

Pada dasarnya pendidikan Islam responsif gender merupakan cara mendidik anak laki-laki dan perempuan secara adil tanpa membersitkan (baik secara sengaja maupun tidak) bahwa salah satu jenis kelamin lebih unggul dibanding jenis kelamin lainnya. Sebagaimana ajaran Islam yang tidak membeda-bedakan atau mengunggulkan jenis kelamin tertentu atas yang lain, kecuali karena ketaatan dan ketaqwaannya kepada Allah SWT.

\section{SEKILAS TENTANG GENDER DAN KONSTRUKSINYA}

Seorang anak sudah dapat dikenali, apakah ia laki-laki atau perempuan sejak ia dilahirkan, yaitu berdasarkan alat kelamin yang dimilikinya. Jika ia memiliki alat kelamin laki-laki maka ia cenderung diarahkan pada hal- hal yang bersifat maskulin, sebaliknya bila ia memiliki alat kelamin perempuan maka ia diarahkan pada hal-hal yang bersifat feminin. Jadi begitu seorang anak dilahirkan, ia memperoleh tugas dan beban gender dari lingkungan budaya masyarakatnya (Nasarudin Umar, 1999: 37). Secara umum, jenis kelamin laki- laki dikaitkan dengan gender maskulin, sementara jenis kelamin perempuan, dikaitkan dengan gender feminin, meski sebenarnya hubungan itu bukan merupakan korelasi absolut (Dewi $\mathrm{H}$ Susilastuti, 1993: 30), sebab gender sebagai sebuah konstruksi sosial sifatnya bervariasi dalam setiap kebudayaan. Jadi tugas dan beban gender seseorang tergantung pada kondisi dan nilai budaya yang berkembang dalam masyarakatnya.

Pengasuhan dan pendidikan anak yang dilakukan oleh sebagian masyarakat Islam selama ini, cenderung bersikap diskriminatif terhadap anak perempuan. Anak laki-laki diberi kesempatan belajar lebih banyak dari anak perempuan. Selain itu anak lakilaki juga diusahakan untuk dapat belajar mempelajari lebih banyak hal dibandingkan anak perempuan, sementara anak perempuan dianggap cukup hanya dengan kepandaian yang berkaitan dengan keperempuanannya (Fuadudin TM, 1999: 1-2). Kebanyakan orang tua juga cenderung berinteraksi dengan anak laki-laki menggunakan aktivitas motorik yang lebih besar dibandingkan ketika berinteraksi dengan anak perempuan. Selain itu, para orang tua juga sering terlibat dalam permainan 
fisik yang lebih keras ketika bermain dengan anak laki-laki.

Pembedaan perlakuan terhadap anak laki-laki dan anak perempuan ini dipengaruhi oleh kultur patriarkhi (Kamla Bashin, 1996:1), yang melihat perbedaan seksual sebagai basis legitimasi untuk melakukan perbedaan peran bagi laki-laki dan perempuan dalam realitas seperti: anak laki-laki harus tegar, gagah dan perkasa karena nantinya akan menjadi kepala keluarga (QS an-Nisa: 34), sementara anak perempuan harus lembut, halus dan keibuan, karena memang sudah selayaknya demikian. Anak laki- laki diposisikan dalam peran publik sementara anak perempuan dalam peran domestik (Mansour Faqih, 1997: 8). Padahal gender tidaklah sama dengan seks atau jenis kelamin. Karena jenis kelamin adalah kenyataan biologis yang terberi yaitu apakah seseorang dilahirkan sebagai perempuan atau laki-laki. Dalam hal ini aspek biologis yang secara mendasar membedakan perempuan dan laki-laki adalah kemampuan perempuan untuk mengandung dan melahirhan (fungsi reprodusi). Kecuali itu, perbedaan lain tidaklah terlalu penting dan substansial.

Pada prinsipnya perbedaan seksual yang bersifat biologis merupakan sebuah kodrat yang telah ditetapkan oleh Tuhan sebagai identitas kemanusiaan yang diciptakan berpasang-pasangan (Qs. AnNaba: 8 dan Qs ar-Ruum: 21-22). Demikian juga dengan perbedaan peran sosial, merupakan keniscayaan yang seharusnya terjadi sebagai proses perimbangan dalam hukum kausalitas alam yang harus saling melengkapi dan membenahi antara keduanya (Nasarudin Umar, 1999: 18-19). Namun dalam realitas sosial yang didominasi oleh budaya patriarkhi sebagai mana disebut di muka, serta adanya bias gender dalam menafsiri teks-teks keagamaan yang selama ini memang didominasi oleh laki-laki (Masdar F Mas’udi, 1996: 50), perbedaan aspek biologis dimanipulasi sedemikian rupa sehingga melahirkan perbedaan peran yang timpang dan lebih menguntungkan laki-laki, yang pada akhirnya memunculkan kesadaran baru bahwa apa yang sesungguhnya “ identitas gender” dianggap sebagai ketetapan dan kodrat Tuhan yang tidak bisa diganggu gugat (John Archer \& Barbara Lloyd, 1982: 10). Misalnya sifat lemah lembut, sifat memelihara dan sifat emosional yang merupakan identitas gender fenimin dianggap sebagai kodrat bagi kaum perempuan. Sebaliknya sifat gagah perkasa, pemberani dan lebih rasional, yang merupakan identitas 
gender maskulin, dianggap sebagai

kodrat bagi kaum laki-laki.

\section{FENOMENA KETIDAKADILAN GENDER DALAM PENDIDIKAN}

Pendidikan berfungsi sebagai alat transformasi sosial, demikian menurut John Dewey. Hal itu menjadi mungkin karena melalui pengajaran yang terorganisir seseorang dapat mengetahui kemampuan dan kekuatan dirinya, serta senantiasa mencari kebenaran. Arah pendidikan dimaksudkan untuk mengembangkan potensi yang dimiliki seseorang seluas-luasnya dan diharapkan dapat menumbuhkan manusia yang mampu berpikir kritis, dan dapat menempatkan diri dalam berbagai situasi yang dihadapi sehingga mampu melakukan kegiatan yang berarti (Paul Kurtz, 1994: 235). Secara normatif, pendidikan nasional di Indonesia bertujuan untuk membangun "manusia Indonesia seutuhnya” sebagai komponen utama dalam pembangunan bangsa dengan tanpa membedakan jenis kelamin, baik itu laki-laki maupun perempuan. Namun demikian walaupun ada jaminan hukum tentang persamaan laki-laki dan perempuan dalam mengakses pendidikan, pada kenyataannya jumlah penduduk perempuan Indonesia yang buta huruf jauh lebih besar dibandingkan penduduk laki-laki (BPS RI, Susenas 2012). Apalagi bila dikaitkan dengan masalah penerapan nilai- nilai adil gender dalam dunia pendidikan, nampaknya secara umum pendidikan di Indonesia masih diwarnai ketimpangan dan ketidakadilan gender.

Dalam dunia pendidikan, pembedaan perlakuan terhadap anak laki- laki dan anak perempuan sepertinya telah menjadi anggapan yang seharusnya terjadi, sehingga terkesan menjadi perlakuan yang telah direncanakan dalam kurikulum walaupun secara eksplisit tidak terumuskan atau yang biasa dikenal dengan istilah hidden curriculm. Adanya pembedaan perlakuan dalam proses pendidikan menyebabkan kurang terlibatnya murid perempuan dalam dinamika kelas. Murid perempuan tidak dirangsang untuk berekspresi dan mengaktualisasikan diri. Sebaliknya, guru banyak memotivasi murid laki-laki sehingga dialog dan diskusi di kelas seringkali didominasi oleh murid lakilaki. Sementara jika ada murid perempuan hendak berpartisipasi maksimal dalam dialog dan diskusi tersebut, tidak diberi kesempatan yang memadai sebagaimana pada murid laki- 
laki. Realitas ini tidak terlepas dari pemahaman yang bias gender, yang melatari para pendidik dalam menatap dua jenis kelamin (Mary Astuti, 2000: 147). Dengan kata lain pendidikan yang terjadi selama ini adalah pola pendidikan yang belum memberikan kesempatan sama terhadap murid laki-laki dan murid perempuan, atau pendidikan yang belum responsif gender. Pola pendidikan yang belum responsif gender ini cenderung merugikan salah satu jenis kelamin yaitu murid perempuan menjadi kurang optimal dalam perkembangannya karena kurangnya kesempatan yang didapatkan untuk mengembangkan minat dan bakat.

Dunia pendidikan yang seharusnya berperan sebagai media transformasi pengetahuan yang berkeadilan gender sehingga dapat memutus mata rantai ketimpangan peran gender, malah sebaliknya, ikut mensosialisasikan nilainilai ketidakadilan gender yang berlangsung secara turun temurun dari generasi ke generasi karena pengaruh konstruksi sosial masyarakat sebagaimana dijelaskan di muka.

\section{KONSEP PENDIDIKAN ISLAM RESPONSIF GENDER}

Konsep pendidikan Islam responsif gender pada dasarnya merupakan antitesis terhadap pola pendidikan yang belum responsif gender yang ada selama ini, baik itu dalam keluarga maupun sekolah. Pendidikan responsif gender ini mengandung arti pendidikan yang didasarkan pada nilai- nilai gender yang memberikan peluang pada akses, partisipasi dan penguasaan terhadap berbagai hal dengan lebih adil. Dengan kata lain model pendidikan ini ingin memberikan kesempatan yang sama terhadap anak didik laki- laki dan anak didik perempuan secara optimal sesuai potensi dan bakat masing- masing.

Kesempatan ini diberikan baik dalam bermain, belajar maupun berketrampilan di lembaga pendidikan formal, non fomal maupun informal. Sementara pendidik bertugas sebagai pembimbing dan pengarah proses aktualisasi minat dan bakat anak tersebut. Dimana hal ini didasarkan pada konsep universalitas Islam yang sangat menganjurkan pada umatnya, baik lakilaki maupun perempuan, untuk menuntut ilmu dan menguasainya sebagai upaya memahami rahasia Tuhan yang tertuang dalam ayat- ayatNya, baik yang berupa ayat kauniyah ( fenomena alam semesta ) maupun yang berupa ayat qauliyah (teks- teks keagamaan). Juga didasarkan pada hadits Nabi yang artinya:"Menuntut ilmu (belajar) adalah 
wajib bagi muslim laki-laki dan muslim perempuan” (H.r. Ibnu Majah No 2241).

Deskripsi hadis di atas menunjukkan bahwa laki-laki dan perempuan sama-berhak mengakses ilmu pengetahuan, sama-sama memiliki kemampuan untuk berpikir, berspekulasi bahkan menganalisis persoalanpersoalan kehidupan, baik dalam bidang sosial, ekonomi, politik, keagamaan dan berbagai bidang lain dalam kehidupan. Universalitas khitab dari perintah menuntut ilmu tersebut, merupakan petunjuk bahwa Islam tidak memperlakukan berbeda laki-laki dan perempuan, dengan pemahaman lebih jauh bahwa konsep pendidikan Islam bukanlah pendidikan yang tidak mengenal nilai-nilai adil gender. Akan tetapi pendidikan Islam justru menjunjung tinggi asas kesetaraan ataupun persamaan hak dan kesempatan bagi laki-laki dan perempuan untuk mengakses ilmu pengetahuan.

Pemberian kesempatan yang sama terhadap anak laki-laki dan anak perempuan dalam Islam dikenal dengan istilah musawah (persamaan), telah diakui sebagai sesuatu yang seharusnya karena dalam Islam terdapat anggapan bahwa mereka diciptakan dari nafs yang sejenis, dimana yang satu tidak memiliki keunggulan atas yang lain (Qs an-Nisa:
1 dan Qs ar-Ruum: 21). Konsekwesinya adalah, sebagai makhluk yang diciptakan dari jenis yang sama, keduanya sama-sama memiliki potensi yang sama untuk berkembang menjadi menjadi makhluk yang termulia disisi Tuhan Sang Pencipta.

Prinsip dasar kesetaraan dalam Islam tersebut merupakan konsep awal untuk tidak berlaku diskriminatif terhadap peserta didik laki-laki maupun perempuan. Dengan demikian berarti bahwa anak laki-laki dan anak perempuan dapat dididik trampil dalam segala bidang secara mandiri dan mampu melakukan tugas apapun asal disesuaikan dengan potensi dan kondisinya. Jadi, tidak harus anak perempuan bersifat feminin, dan anak laki-laki bersifat maskulin, karena pada dasarnya kedua sifat tersebut bisa dimiliki oleh anak laki-laki maupun anak perempuan hal ini biasanya dikenal dengan istilah androgini (Sartini Nuryoto, 1999: 72-73).

Pendidikan dengan metode Androgini ini marak menjadi bahan diskusi di kalangan kaum feminis pada tahun 1970an. "Andro" berasal dari bahasa latin, artinya pria dan "gyne" artinya perempuan. Pendidikan androgini merupakan pendidikan yang memperkenalkan konsep bebas gender 
kepada anak laki-laki dan anak perempuan (Ratna Megawangi, 1999: 114), konsep pendidikan yang memperlakukan laki-laki dan perempuan tanpa membedakan jenis kelaminnya. Tidak seperti pendidikan konvensional yang berasumsi bahwa laki-laki dan perempuan berbeda secara jenis kelamin dan harus dibeda-bedakan. Pendidikan yang menggunakan pendekatan kesesuaian peran jenis kelamin ini biasanya mengarah pada pembakuan peran gender tertentu misalnya pembentukan karakter feminin bagi perempuan dan karakter maskulin bagi laki-laki (Elly Nurhayati, 1999: 236237).

Meskipun Kenneth Kemmeyer sebagaimana dikutip Ratna Megawangi mengkritik pendidikan androgini dengan mengatakan:

"Ironis, laki-laki dan perempuan yang dibesarkan secara androgini dapat menjadi miskin dibandingkan dengan rekan mereka yang lebih cenderung menyesuaikan dirinya kepada harapan peranan gender tradisional... Anak- anak yang tumbuh secara androgini akan dihukum di luar dunia tradisionalnya. Sebagai hasilnya, mereka akan menjadi tidak efektif dan tidak bermanfaat”.

Namun dalam beberapa penelitian tentang karakteristik kepribadian lakilaki dan perempuan, seperti yang dilakukan oleh Sandra L Bem menunjukkan bahwa laki-laki dengan karakteristik maskulin dominan dan perempuan dengan karakteristik feminin dominan, keduanya memiliki daya adaptasi yang relatif rendah dalam kehidupan ini. Hasil penelitiannya menemukan bahwa ada satu jenis karakter kepribadian yang lebih unggul, lebih adaptif karena dianggap lebih mampu menyelesaikan berbagai persoalan kehidupan secara konstruktif, yaitu karakter yang ditandai dengan kesepadanan dominasi unsur feminin dan unsur maskulin (Sandra L Bem, 1974: 155-162). Karakteristik kepribadian semacam ini disebut androgyny. Semakin tinggi androginitas seseorang, maka dia akan lebih adaptif dan mampu menyelesaikan berbagai masalah secara konstruktif. Anak-anak yang memiliki sifat androgini akan mampu bersifat lemah lembut, tegas dan luwes dalam menghadapi kenyataan hidup. Mereka dapat mewujudkan secara tepat kapan harus bersikap feminin dan kapan harus bersifat maskulin.

Pendidikan Islam responsif gender adalah pendidikan yang didasarkan pada nilai-nilai adil gender yang lebih memberikan kesempatan yang sama bagi anak laki-laki dan anak perempuan dalam mengembangkan potensinya, 
demi terwujudnya tatanan masyarakat yang adil dan damai sesuai dengan semangat nilai-nilai ajaran Islam.

Hal ini diinspirasi oleh sebuah pemahaman bahwa Islam secara konseptual sebagaimana tertuang dalam al-Qur'an maupun secara praksis sebagaimana yang dicontohkan Nabi Muhammad Saw, mengandung nilainilai universal yang memberikan ruang yang sama bagi laki-laki dan perempuan untuk berperan dalam pentas kehidupan. Hanya karena perjalanan waktu dan pemahaman umatlah yang menyebabkan tampilan Islam terkesan mendiskreditkan perempuan. Padahal jika ditilik dari sumber kitab suci dan risalah kenabian dalam Islam, tidak dipungkiri bahwa Islam adalah agama yang sangat revolusioner dalam menyetarakan posisi laki-laki dan perempuan, yang saat itu masih sangat patrialkhal dengan tradisi jahiliyahnya.

Dari segi tujuan pendidikan Islam, tidak dijumpai adanya pembedaan antara laki-laki dan perempuan, akan tetapi dari segi materi dan metode pembelajaran, masih terlihat kecenderungan mengutamakan jenis kelamin tertentu. Materi pendidikan yang di dalamnya tersimpan pesan-pesan peran gender tertentu disosialisasikan terus menerus sehingga alam bawah sadar anak menganggap itu sebagai sesuatu yang seharusnya. Realitas tersebut semakin diperkuat oleh guru sebagai penyelenggaran pendidikan.

\section{MENUJU PENDIDIKAN ISLAM RESPONSIF GENDER}

Pendidikan responsif gender merupakan pengembangan dan pembakuan konsep androginitas yang hendak disosialisasikan secara sistematis dan terrencana, baik dalam lingkungan formal, informal maupun nonformal. Prinsip androginitas yang digulirkan oeh beberapa kalangan feminis ini merupakan alternatif tawaran sistem yang diharapkan dapat memicu kesadaran para pendidik, pengelola pendidikan dan anak didik dalam melakukan interaksi dengan lingkungan sekitar.

Konsep pendidikan responsif gender berusaha menghadirkan suasana dan kondisi lingkungan yang tidak bias gender, dimana untuk membangun lingkungan seperti itu harus diawali dengan persepsi bahwa anak-anak akan tumbuh dan berkembang sesuai dangan potensi dasariahnya secara optimal tanpa dibatasi ruang geraknya oleh sekat-sekat kelamin yang berunsur biologis.

Namun demikian bukan berarti model pendidikan responsif gender ini 
bermaksud untuk mengaburkan identitas seksual (jenis kelamin) seseorang, tetapi lebih dimaksudkan untuk memunculkan potensi positif anak laki-laki maupun anak perempuan, demi kesuksesan mereka kelak sebagai manusia Indonesia seutuhnya. Juga bukan berarti pendidikan responsif gender ini kemudian menyamakan peran atau identitas seksual laki-laki dan perempuan, atau pendidikan yang melawan kodrat. Sebab peran seksual yang merupakan kodrat Tuhan akan berkembang secara alamiah dan naluriah, di mana laki-laki dengan testisnya sebagai penghasil sperma dan perempuan dengan ovariumnya sebagai penghasil sel telur. Peran-peran kodrati ini tidak akan hilang sebab ini merupakan peran yang dipengaruhi oleh insting dasar makhluk hidup, yakni meneruskan keturunan untuk mempertahankan habitatnya.

Adapun mengenai beberapa langkah yang bisa ditempuh dalam rangka mewujudkan idealitas tersebut adalah: pertama, pembenahan kurikulum. Kurikulum merupakan bagian penting yang ikut menentukan terwujudnya kesetaraan gender. Relasi kekuasaan antara laki-laki dan perempuan serta semua persoalan kesetaraan selalu akan terrefleksi dalam sebuah kurikulum, karenanya kurikulum yang sensitif gender harus dipastikan adanya. Berdasarkan tinjauan terhadap kurikulum pendidikan sekolah, terutama di tingkat dasar, masih menunjukkan kekentalan dalam memisahkan peran perempuan dan laki-laki. Perempuan digambarkan dengan peran kerumahtanggaannya, sementara laki-laki digambarkan dengan perannya dalam sektor publik. Realitas bahwa perempuan yang bekerja di sektor publik saat ini memang sudah cukup banyak jumlahnya dan meluas di berbagai bidang tetapi profesi dan jabatan yang diberikan dan diduduki perempuan masih banyak berhubungan dengan pekerjaan-pekerjaan subsistensi atau yang dianggap sesuai dengan sifat-sifat perempuan. "Ibu memasak didapur, ayah pergi ke kantor”, lazimnya secuplik kalimat tersebut juga dilengkapi gambar ilustratif agar peserta didik lebih imajinatif dalam memahami deretan kata-kata itu. Konstruksi sosial yang tertuang dalam materi pembelajaran tersebut, akan terinternalisasi dalam diri peserta didik sebagai bagian dari pengetahuan yang dimilikinya.

Selain sebagai pengetahuan, apa yang telah didapatkan dalam pembelajaran tersebut juga akan terinternalisasi menjadi sikap yang 
secara langsung berpengaruh pada perilaku sehari-hari peserta didik ketika harus berinteraksi dengan teman, pendidik maupun lingkungan sekitar. Hal ini merupakan proses pendefinisian peserta didik terhadap realitas kehidupannya.

Ilustrasi diatas menunjukkan bahwa kurikulum sebagai bagian dari proses pembelajaran merupakan persoalan yang penting dan pembenahan kurikulum merupakan hal yang harus ditangani secara serius. Persoalannya jelas, segala relasi kekuasaan antara laki-laki dan perempuan serta segala persoalan kesetaraan akan selalu terrefleksi dalam sebuah kurikulum. Jadi ketika kurikulum pendidikan yang digunakan oleh sebuah insitusi pendidikan tidak sensitif gender, maka hal ini akan berpengaruh pada kesadaran gender yang dimiliki oleh out put dari insitusi pendidikan tersebut. Oleh karena itu, formasi kurikulum yang responsif gender harus dipastikan ada di setiap institusi pendidikan.

Kedua, peningkatan profesionalisme pendidik. Seringkali para pendidik tidak menyadari bahwa perlakuannya terhadap peserta didik masih sarat dengan nilainilai yang kurang sensitif gender. Secara umum mereka mengaku telah memperlakukan peserta didik laki-laki dan perempuan dengan adil, padahal beberapa penelitian menunjukkan bahwa kebanyakan pendidik masih memandang beda terhadap peran maupun posisi peserta didik karena jenis kelamin mereka (Janet A Kourani et all, 1992: 37).

Hal ini juga secara tidak langsung dipengaruhi oleh ketidaktahuan pendidik bahwa ternyata materi pelajaran yang disampaikan kebanyakan belum responsif gender (Mary Astuty, 2000: 147). Sehingga pendidik merasa tidak ada yang salah ketika yang banyak disuruh mengerjakan soal matematika adalah anak laki-laki, sementara yang lebih banyak disuruh meyanyi adalah anak perempuan. Begitu juga dengan perhatian yang lebih banyak diberikan pada anak yang menunjukkan jari yang kebanyakan adalah anak laki-laki. Pendidik seringkali tidak menyadari bahwa anak yang diam, anak yang tidak menunjukkan jari untuk menjawab pertanyaan boleh jadi anak yang pandai tapi malu karena umumnya mereka anak perempuan yang kurang berani menyampaikan pendapat, anak perempuan yang tidak diberi kebebasan di rumah, di mana anak perempuan harus selalu patuh dan menurut perintah orang tua, tanpa disadari kebiasaan tersebut terbawa ke sekolah sehingga 
kalau tidak disuruh, mereka tidak berani menyatakan pendapatnya.

Ilustrasi di atas menunjukkan bahwa yang harus diperhatikan selain masalah pembenahan kurikulum adalah masalah peningkatan profesionalitas pendidik. Hal ini menjadi penting karena meskipun kurikulumnya sudah responsif gender tapi kalau kesadaran dan sensitivitas gender pendidik masih rendah, maka akan sulit mewujudkan kondisi dan lingkungan yang adil gender. Selain itu, cara pengajaran yang digunakan oleh pendidik juga sangat menentukan. Jadi harus ada model pengajaran yang responsif gender, di mana guru dalam pengajarannya tidak bersikap konvensional serta tidak memakai bahasa-bahasa yang bias gender. Para pendidik hendaknya mengenalkan nilai-nilai adil gender dalam menyampaikan materi pelajaran, juga memberikan kesempatan yang sama pada murid laki-laki dan murid perempuan untuk mengaktualisasikan dirinya dengan baik.

\section{PENUTUP}

Islam adalah agama yang
mempunyai konsep cukup jelas dan
perhatian yang tinggi tentang kesetaraan
pendidikan antara anak laki-laki dan
anak perempuan, yang bila diamati

belum dikembangkan dan diaplikasikan dengan baik dalam kehidupan masyarakat muslim. Dalam rangka mewujudkan nilai-nilai kesetaraan antara laki-laki dan anak perempuan sebagaimana yang dicita-citakan oleh Islam, tidak ada alasan untuk berlaku diskriminitif terhadap peserta didik lakilaki maupun perempuan. Perlakuan yang tidak diskriminatif ini dapat diwujudkan melalui penyusunan kurikulum maupun dalam proses pembelajaran secara menyeluruh, sehingga dengan demikian maka doktrin Islam sebagai agama yang menjunjung tinggi harkat dan martabat manusia (khususnya perempuan) tidak hanya menjadi slogan belaka.

Adakah harapan terwujudnya dunia pendidikan yang responsif gender di masa depan? Pekerjaan berat tapi mau tidak mau harus dilakukan demi perbaikan kualitas sebuah bangsa.

\section{DAFTAR PUSTAKA}

Nasaruddin Umar, Argumen Kesetaraan Jender dalam Perspektif alQur'an, Jakarta: Paramadina, 1999.

Dewi H Susilastuti, Gender ditinjau dari Perspektif Sosiologis, dalam Fauzi Rijal et. All, Dinamika Gerakan Perempuan di Indonesia, Yogyakarta: Tiara Wacana,LSPPA, Perpustakaan Yayasan Hatta dan FES, Desember, 1993. 
Fuadudin TM, Pengasuhan Anak dalam Islam, Jakarta: Lembaga Kajian Agama dan Jender, 1999.

Kamla Bashin, Menggugat Patriarkhi, Yogyakarta: Bentang Budaya, 1996.

Mansour Faqih, Analisis Gender dan Transformasi Sosial, Yogyakarta: Pustaka Pelajar, 1997.

Masdar F Mas'udi, Islam dan Hak-hak Reproduksi Perempuan, Bandung: Mizan, 1996

John Archer dan Barbara Lloyd, Sex and Gender, London: Penguin Books, 1982.

Sidney Hook, "Filsafat Pendidikan John Dewey" dalam Sidney Hook: Sososk Filsuf Humanis, Demokrat dalam Tradisi Pragmatisme, ed. Paul Kurtz, Jakarta: YOI, 1994.

Ace Suryadi, "Perempuan Indonesia dalam Peta Pendidikan" dalam Agama dan Jender News, Edisi 12, 2002.

Mary Astuty, "Pendidikan Berperspektif Gender" dalam Membuka Masa Depan Anak-anak Kita; Mencari Kurikulum Pendidikan Abad XXI, Ed. Sindhunata, Yogyakarta: Kanisius, 2000.

Sartini Nuryoto, "Pola Asuh Anak" dalam Sosialisasi Gender
Menjinakkan Takdir Mendidik Anak Secara Adil, ed. Lusi Margiyani dan Yasir Alimi, Yogyakarta: LSPPA dan Ford Foundation, 1999.

Ratna Megawangi, Membiarkan Berbeda, Bandung: Mizan, 1999.

Elly Nurhayati, "Tantangan keluarga pada Millenium ketiga" dalam Sosialisasi Gender Menjinakkan Takdir Mendidik Anak Secara Adil, ed. Lusi Margiyani dan Yasir Alimi, Yogyakarta: LSPPA dan Ford Foundation, 1999.

Sandra L Bem, "The Measurement of Psychological Androgyny” dalam Journal of Counsulting and Clinical Psychology, Stanford University, 1974, Vol. 42, No. 2.

Janet A Kourany, James P Sterba, Rosemarie Tong, Feminist Philosophies, New Jersey: Prentice Hall, Englewood Cliffs, 1992.

Mary Astuty, "Pendidikan Berperspektif Gender" dalam Membuka Masa Depan Anak-anak Kita: Mencari Kurikulum Pendidikan Abad XXI, ed: Sindhunata, Yogyakarta: Kanisius, 2000, hlm. 147.

BPS RI, Hasil Survey Sosial Ekonomi Nasional, 2012. 